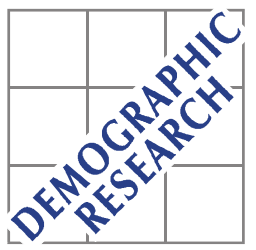

Demographic Research a free, expedited, online journal

of peer-reviewed research and commentary in the population sciences published by the Max Planck Institute for Demographic Research

Konrad-Zuse Str. 1, D-18057 Rostock · GERMANY

www.demographic-research.org

DEMOGRAPHIC RESEARCH

VOLUME 27, ARTICLE 7, PAGES 167-200

PUBLISHED 2 AUGUST 2012

http://www.demographic-research.org/Volumes/Vol27/7/

DOI: 10.4054/DemRes.2012.27.7

Research Article

Living arrangements, intergenerational support types and older adult loneliness in Eastern and Western Europe

Jenny de Jong Gierveld

Pearl A. Dykstra

Niels Schenk

This publication is part of the proposed Special Collection "Intergenerational family ties in Europe: Multiple linkages between individuals, families and social contexts", edited by Pearl Dykstra.

(C) 2012 de Jong Gierveld, Dykstra \& Schenk.

This open-access work is published under the terms of the Creative Commons Attribution NonCommercial License 2.0 Germany, which permits use, reproduction \& distribution in any medium for non-commercial purposes, provided the original author(s) and source are given credit.

See http:// creativecommons.org/licenses/by-nc/2.0/de/ 


\section{Table of Contents}

$\begin{array}{llr}1 & \text { Introduction } & 168\end{array}$

$2 \quad$ Background 170

$2.1 \quad$ Living arrangements and loneliness 170

2.2 Intergenerational support and loneliness 172

2.3 Hypotheses 174

$3 \quad \begin{array}{ll}\text { Dependent variable } & 175 \\ \text { Method } & \text { Samples }\end{array}$

3.1 Samples 175

3.2 Measuring instruments 177

$\begin{array}{lll}3.2 .1 & \text { Dependent variable } & 177\end{array}$

$\begin{array}{ll}\text { 3.2.2 Explanatory variables } & 177\end{array}$

$\begin{array}{lll}3.2 .3 & \text { Control variables } & 178\end{array}$

$\begin{array}{lll}3.3 & \text { Analyses } & 179\end{array}$

$4 \quad$ Results 179

$\begin{array}{lll}4.1 & \text { Background characteristics } & 179\end{array}$

4.2 Typology of intergenerational support 180

4.3 Loneliness 183

$\begin{array}{lll}4.4 & \text { East-West contrasts } & 184\end{array}$

5 Discussion 187

$6 \quad$ Acknowledgments 190

$\begin{array}{ll}\text { References } & 191\end{array}$

$\begin{array}{ll}\text { Appendix } & 199\end{array}$ 


\title{
Living arrangements, intergenerational support types and older adult loneliness in Eastern and Western Europe
}

\author{
Jenny de Jong Gierveld ${ }^{1}$ \\ Pearl A. Dykstra ${ }^{2}$ \\ Niels Schenk ${ }^{3}$
}

\begin{abstract}
BACKGROUND

Previous research has shown that living arrangements (independent households of those living alone or as a couple, versus coresident households encompassing adult children) are important determinants of older adults' loneliness. However, little is known about intergenerational support exchanges in these living arrangements and their associations with loneliness.
\end{abstract}

\section{OBJECTIVE}

Our aim is to contribute to the knowledge on associations between living arrangements and loneliness, by taking into account and differentiating intergenerational support types.

\section{METHODS}

Using data from the Generations and Gender Surveys of three countries in Eastern Europe and two countries in Western Europe, Latent Class Analyses was applied to develop intergenerational support types for (a) co-residing respondents in Eastern Europe, (b) respondents in independent households in Eastern Europe, and (c) respondents in independent households in Western Europe, respectively. Six types resulted, distinguishing patterns of upward support, downward support and gettogethers. Subsequently, we used linear regression analyses to examine differences in loneliness by region, living arrangements and intergenerational support type.

\footnotetext{
${ }^{1}$ Netherlands Interdisciplinary Demographic Institute (NIDI), The Hague; Faculty of Social Sciences, VU University, Amsterdam.

${ }^{2}$ Erasmus University, Rotterdam.

${ }^{3}$ Erasmus University, Rotterdam.
} 


\section{RESULTS}

Findings show higher levels of loneliness in Eastern than in Western Europe. Older adults living alone are most lonely, older adults living with a partner are least lonely. Coresidence provides protection, but not to the same degree as a partner. In both coresident and independent households there is a greater likelihood of being involved in support given to adult children than in support received from adult children. In both East and West European countries, older adults who are primarily on the receiving side are most lonely.

\section{CONCLUSIONS}

A better explanation of older adult loneliness is obtained if the direction of supportive exchanges with adult children is considered than if only living arrangements are considered.

\section{Introduction}

The classic volume on old age by Rosow (1967), and his observation that the most significant problems of older adults are intrinsically social, forms the starting point of the present paper. What factors contribute to older adults' integration in society? People are socially integrated when their lives are tied to the lives of others, a process that is strongly shaped by work, family, and neighborhood roles. At work, people interact with colleagues, clients and others. Over the years, shared conversations and experiences contribute to a sense of belongingness in the work setting as well as the society at large (Hagestad and Uhlenberg 2006). Marriage tends to provide feelings of emotional connectedness (De Jong Gierveld et al. 2009; Waite and Gallagher 2000), but differently so for men and women (Dykstra and De Jong Gierveld 2004). As Chodorow (1978) has argued, men tend to rely on their spouses for support, whereas women are socialized to have more complex affective needs in which an exclusive relationship with a spouse is not enough. Children serve as bridges to new social circles for their parents through involvements at daycare, school, clubs, sports, and the local community (Dykstra 2006; Furstenberg 2005).

In this paper we focus on social integration as a subjective experience. More specifically, we address feeling not socially integrated; that is, feeling lonely. Perlman and Peplau (1981: 38) define loneliness as "the unpleasant experience that occurs when a person's network of social relations is deficient in some important way, either quantitatively or qualitatively." Loneliness needs to be differentiated from social isolation. The latter is an objective situation and refers to the absence of relationships 
with other people (Cornwell and Waite 2009). Loneliness is a subjective and negative experience, the outcome of the evaluation of the match between the quantity and quality of existing relationships and one's relationship desires or standards. Some people having a restricted social network feel lonely, others do not.

Studies have repeatedly shown that older adults who are in poor health, have difficulty making ends meet, have poor social skills, and/or live alone are most prone to loneliness (for reviews see Pinquart and Sörensen 2001; Victor et al. 2000). These factors represent obstacles to experiencing rewarding social involvements, and make people more vulnerable to loneliness (Hawkley et al. 2008). Much of the loneliness research has focused on the protective role of the partner, examining marital history differences (e.g., Dykstra and De Jong Gierveld 2004; Pinquart 2003; Stevens and Westerhof 2006) or the spouse's health condition (e.g., Korporaal, Broese van Groenou and Van Tilburg 2008). Of course, being without a partner is not identical to living alone. Nevertheless, relatively little loneliness research has focused on the extent to which interactions with household members other than a partner help to alleviate or prevent loneliness in the older adult population. This issue is particularly relevant in Eastern and Southern Europe, where rates of intergenerational coresidence are higher than in other industrialized countries (Hank, 2007; Tomassini et al. 2004, Treas and Cohen 2006). In this study we will consider both partner status and intergenerational co-residence, and examine variations in loneliness by older adults' living arrangement (single, with a partner, and/or with adult children).

When parents and adult children share a household, the direction of intergenerational transfers is not always clear (Cohen and Casper 2002; Smits, Van Gaalen and Mulder 2010). Who is supporting whom? As Treas and Cohen (2006) have argued, it is important to complement information on living arrangements with information on the flow of assistance up and down generational lines. In this paper, we look at exchanges of support within the coresidential unit. In addition, we "look beyond the household" (Grundy, Murphy and Shelton 1999) to document transfers and gettogethers of adult children and their parents who are living independently of one another.

Data come from the Generations and Gender Surveys, carried out under the auspices of the United Nations (Vikat et al. 2007). France, Germany, Bulgaria, Russia and Georgia are included in our analyses. We improve upon the literature in three ways. Going beyond the customary focus on Western Europe, we also include East European countries in our study. We not only focus on living arrangements, but also examine exchanges with adult children both in and outside the household. We identify configurations of exchanges by developing a typology of support (Dykstra and Fokkema 2011; Hogan, Eggebeen and Clogg 1993; Silverstein and Bengtson 1997; Van Gaalen and Dykstra 2006) rather than focus on single dimensions of support. 


\section{Background}

\subsection{Living arrangements and loneliness}

In recent decades, the proportion of older persons living alone has increased in all regions of the world (United Nations Department of Economic and Social Affairs/Population Division 2005). There is a greater tendency for women, compared to men of the same age, to live alone, and there is a greater tendency for older elderly people compared to their younger counterparts to live alone. The reason more women live alone is that women are more likely to be widowed. Rates of solitary living generally increase with age, given the increasing likelihood of losing the partner by death, and the increasing likelihood of children's departure from the parental home.

There is considerable cross-national variation in levels of solitary living. Within Europe, the proportion of older men and women living alone is higher in the North and West than in the South and East. "Generational economics" (Therborn 2004: 312), an interaction of generational dependence and economic resources, are behind single living. Sufficient independent income enables young adults and the older people to maintain their own households. General prosperity facilitates this more widely, but specific housing markets may keep young people in their parental home, and the absence of affordable public residential and home care may necessitate intergenerational coresidence for those in need of assistance.

In a number of countries, the increase in proportions living alone has slowed, halted or reversed. Data reported by Tomassini et al. (2004) show that the proportion of women aged 65 and over living alone has declined recently in Austria, Germany, and Italy. The reasons involve a combination of improvements in mortality, which decrease the proportion of widowed, declines in the proportion who never married, and increases in the age at which children left home. Counter-tendencies are also observed in selected countries of the former Soviet Union such as the Ukraine, where the socioeconomic crisis resulted in higher levels of coresidence of older people and their adult children due to greater financial hardship (Bezrukov and Foigt 2002).

Those living alone are more likely to need outside assistance in the case of illness or disability, and they must turn to people outside their household for the fulfillment of their social and emotional needs. Nevertheless, living alone should not be equated with feeling lonely. Research has shown that older adults who live alone, but have supportive social networks, rewarding solitary activities, and/or attach much importance to privacy and autonomy are not prone to loneliness (Dykstra 1993; Zettel and Rook 2004). Jylhä and Jokela (1990) found that levels of loneliness among older adults living alone were higher in countries where solitary living was rarest. The authors point to the importance of considering people's frames of reference and normative orientations in 
the cultural context of countries under investigation. In the more familialistic societies of Southern Europe with their low proportion of one-person households, living alone might not be a situation older adults expect. In the more individualistic societies of Northern Europe, older adults seem more content living alone and might view coresidence with children as a defeat.

Intergenerational coresidence is a vehicle for the exchange of social, emotional, practical, and financial support. It is unlikely, however, that the support provided by a coresident child confers the same psychological benefits as the support once provided by the partner (Weiss 1974). For that reason, one might expect to find higher levels of loneliness among older adults living with their adult children than among peers who are part of a couple. Research findings are mixed. Wenger (1984), for example, found that the very old in Wales who were living with their children were more lonely than those who lived alone. De Jong Gierveld and Van Tilburg (1999) reported lower levels of loneliness, compared to those living alone, for their Italian sample of older adults, but higher levels of loneliness for their Dutch sample. In their study of Chinese older adults, Chen and Short (2008) found that coresidence with immediate family (spouse or children) was associated with better subjective well-being, including lower levels of loneliness and feelings of social isolation.

The findings suggest that the association between coresidence and loneliness differs by cultural and economic context, as in the case of the association between solitary living and loneliness. Where the residential independence of ageing parents and adult children is valued and feasible, such as in Northern and Western Europe, coresidence is associated with greater older adult loneliness. In these countries, the preferred living arrangement is "intimacy at a distance" (Rosenmayr and Köckeis 1963): frequent contacts between adult children and their parents, but not a shared living arrangement. Presumably, coresidence-insofar it happens-is compelled by necessity rather than emotional closeness, leading to tensions, conflict, and mutual isolation. In societies where multigenerational households are the traditional institutional arrangement, such as in Eastern and Southern Europe, coresidence is associated with less older adult loneliness. Here, coresidence is consistent with normative ideas about family responsibilities and family cohesiveness, and presumably helps promote feelings of inclusiveness and belonging.

In summary, our hypotheses on living arrangement differences in loneliness are informed by two perspectives. The first is Weiss's (1974) theory of the social provisions of relationships: attachment, reassurance of worth, guidance, reliable alliance, social integration, and opportunity to provide nurturance. We predict that older adults living with a partner are best protected against loneliness (see e.g. Sundström et al. 2009) because that relationship supplies the widest range of social and emotional resources. We predict furthermore that older adults without partners, living with adult 
children are next best protected against loneliness. Though adult children typically provide a wide range of supports, they cannot fully compensate for the absence of a partner. Finally we predict that those living alone are most poorly protected against loneliness because they must seek fulfillment of their social emotional needs in relationships outside their household. Our second theoretical premise is that living arrangement differences in loneliness are shaped by normative ideas about family responsibilities and shared households. We predict that living alone makes older adults more vulnerable to loneliness in East European countries than in West European countries because residential autonomy and privacy are more highly valued in the latter. We predict furthermore that living with adult children makes older adults more vulnerable to loneliness in West European countries than in East European countries because intergenerational coresidence is not in accordance with expectations and preferences in the former.

\subsection{Intergenerational support and loneliness}

As Hagestad (2000) has argued, coresidence might be a matter of degree. Adult family members might not be living together, but nevertheless quite close: in the same building, street, or neighbourhood. Hank (2007) revealed that eighty-five percent of European parents aged 50 years or older have at least one child with whom they share a household or who lives within a 25-km distance. Faster methods of communication (telephone, electronic mail) and travel (car, air) have facilitated contact among family members who do not live close to each other (Ajrouch, Akiyama and Antonucci 2007). As noted earlier, coresidence patterns provide little insight into the question of who is supporting whom. For these reasons, we also consider exchanges with adult children living outside the older adults' household. We not only look at the direction of exchanges (up and down generational lines), but also at several kinds of interactions which can be subsumed under Bengtson and Roberts' (1991) concepts of "functional solidarity" (practical help) and "associational solidarity" (frequency of get-togethers).

There are contrasting views on the benefits of giving and receiving support. From

an exchange theory perspective, all giving involves costs (Emerson 1976), and too much giving, or giving to too many recipients, may come to involve too high costs. Altruism theory provides a contrasting view, that giving support is not a pure cost but also brings rewards. The act of giving is respected and esteemed, and there are benefits in the sense of being valued by and being important to others (Batson 1998). The directeffect model of social support (Cohen and Wills 1985) posits that receiving social support is beneficial because it helps people stay healthy, maintain an overall sense of stability and self-worth, and helps them in their efforts to improve their situation. 
According to equity theory (Walster, Walster and Berscheid 1978), the receipt of support is not always beneficial. Receiving more support than one gives leads to distress and guilt, whereas receiving less support than one gives is a source of distress because people feel exploited and unfairly treated. From an equity perspective, a balanced exchange promotes wellbeing.

Research consistently shows that intergenerational support flows primarily downward-from old to young-or is balanced (Albertini, Kohli and Vogel 2007; Attias-Donfut, Ogg and Wolff 2005; Schröder-Butterfill 2004; Oppong 2006). Parents become net beneficiaries of help only at an advanced age. Moreover, adults in need of help are not only at the receiving side: "A person who is physically dependent may still be a great correspondent, a raconteur, or a great listener. The care giving relationship need not always be as one-sided as it might appear on the surface” (Kahana and Young 1990: 79). Care-givers and care-recipients often negotiate a finely tuned set of reciprocities in their relationship (Finch 1995; Nolan, Grant and Keady 1996).

In developing our predictions, we explicitly consider the specifics of parenthood, which are neatly summarized in the subtitle of a recent paper by Levitzki (2009): "Parents are always parents". Following the wide body of literature that has emphasized the centrality of parenthood in the lives of aging individuals (see Dykstra and Hagestad 2007 for an overview), we argue that giving to adult children nourishes older adults' identity and promotes their wellbeing.

Again, we expect to find differences between West European and East European countries. We are informed by Adams, Anderson, and Adonu (2004) who conceptualize intimacy and closeness within families as culturally specific. In familialistic societies, people have an interdependent concept of self, and their identity is constructed in relation to others. In these cultures, intimacy is defined as "interpersonal responsiveness to relational obligations". In individualistic countries, independent constructions of self are prevalent, and definitions of intimacy emphasize "disclosure of personal experience and feelings" (Adams et al. 2004: 324-325). The more interdependent cultural values are typical of Southern and Eastern Europe, whereas the more independent cultural values are typical of Western and Northern Europe (see also Höllinger and Haller 1990; Viazzo 2010). In Eastern Europe, relationships with adult children are driven by more binding mutual obligations, and older adults expect to continue to care for their offspring, if possible, and to be cared for by their offspring, in case of need. Receiving practical help from younger family members is positively valued and contributes to feelings of social integration. In Western Europe, relationships with adult children are less strongly governed by duty norms, and companionship and emotional closeness are valued. Receiving practical help from children has a negative connotation, particularly if received favours cannot be reciprocated. 
Several countries in Central and Eastern Europe have been confronted with large scale financial strain and income insecurities following the transitions of 1989/1990. The privatisation of the means of production after 1989 brought about a profound restructuring of agriculture and industry, which was accompanied by job insecurity and the loss of long-term socialist rights (Thelen 2006). Petrov (2007) has described the ways in which these negative economic and social changes in the countries of Central and Eastern Europe have increased income inequalities, produced more poverty, led to more unhealthy behaviour, together with reductions in life expectancy and more psychosocial stress. As far as the position of older people is concerned, intergenerational relationships have changed fundamentally. During socialism it was customary that elderly parents used their savings to help adult children. After the economic crises of the 1990s pension schemes deteriorated and for the majority of older adults it is became difficult to pay everyday expenses. Many of the older adults now have to rely on the financial help of children, who themselves are confronted with very high levels of unemployment, decreasing income levels and increasing housing costs (Robila 2004). It is well documented that financial strain is associated with greater psychological distress and a greater likelihood of interpersonal conflicts. Older adults in these circumstances are less optimistic and feel unable to control unwanted things that happen in their lives (Krause, Newsom and Rook 2008). Economic insecurity, deteriorating public health services, and political upheavals have weakened feelings of social integration and increased the risks of loneliness among older adults in Eastern Europe (Rokach et al. 2001).

\subsection{Hypotheses}

The previous considerations bring us to the following hypotheses:

- H1: Older adults living with a partner are least lonely, followed by those living with adult children, whereas those who live alone are most lonely.

- H2: The difference in loneliness between older adults living with a partner and those living alone is greater in East European countries than in West European countries.

- H3: The difference in loneliness between older adults living with a partner and those living with adult children is greater in West European countries than in East European countries.

- H4: Older adults who are not engaged in any exchanges or interactions with their adult children are most lonely, followed respectively by those who are primarily on the receiving side, those engaged in both upward and downward exchanges, and those who are primarily on the giving side. 
- H5: The negative association between get-togethers oriented towards exchanges of emotional closeness and companionship, and older adult loneliness is weaker in East European countries than in West European countries.

- H6: The positive association between being primarily on the receiving side and older adult loneliness is stronger in West European countries than in East European countries.

- H7: The negative association between being primarily on the giving side and older adult loneliness is weaker in East European countries than in West European countries.

\section{Method}

\subsection{Samples}

The data for France, Germany, Russia, Bulgaria and Russia are from the harmonized public release file of the first wave of the Generations and Gender Surveys (GGS). A consortium of national statistical offices, demographic institutes, and universities was involved in the development of the fieldwork guidelines, which specify random sampling of the resident, non-institutionalized population aged 18 to 79 years. Sample sizes varied between 9,604 for Germany and 12,828 for Bulgaria. We selected the data on older adults, that is women and men aged 60 years and over. Sample sizes per country for this age group are 2266 or above. All countries followed the centrally developed questionnaire, with some nationally specific adjustments. In Russia, Bulgaria and Georgia, interviewers used paper and pencil questionnaires, whereas France and Germany used computer-assisted methods. All data sets were cleaned according to centralized guidelines, followed by a data harmonization phase.

So far, analyses of the representativeness of GGS-data have largely focused on their usefulness for gaining insight into fertility and marriage trends. Results have revealed few and minor discrepancies between GGS estimates on the one hand, and vital statistics and micro- censuses on the other hand, with one exception (Kreyenfeld et al. 2010; Neels, De Winter and Vermant 2011). In the German GGS completed fertility in the older cohorts is underestimated, partly because childless women are overrepresented and partly because children who have left the parental home appear to be underreported. It is unclear whether the underrepresentation of nonresident adult children in the German sample implies that reports of the quality and exchanges of parent-child relationships are also substantively biased. Nevertheless, we advise some caution in interpreting the German findings. 
Table 1: Selected countries: Demographic and economic indicators

\begin{tabular}{lccccc}
\hline & France & Germany & Russia & Bulgaria & Georgia \\
\hline $\begin{array}{l}\text { Population size* } \\
\text { Percentage population }\end{array}$ & $60,940,00$ & $82,728,600$ & $141,900,400$ & $7,615,000$ & $4,395,800$ \\
$\begin{array}{l}\text { aged 60+* } \\
\quad \text { Female }\end{array}$ & 24.3 & 28.3 & 21.1 & 25.6 & 20.5 \\
$\quad$ Male & 19.3 & 22.2 & 12.5 & 20.1 & 15.3 \\
Life expectancy at & & & & & \\
birth* & & & & & \\
$\quad$ Female & 83.5 & 82.1 & 71.8 & 76.3 & 74.8 \\
$\quad$ Male & 76.5 & 76.3 & 58.7 & 69.8 & 67.1 \\
Life expectancy at 60* & & & & & \\
$\quad$ Female & 26.0 & 24.5 & 19.2 & 20.1 & 20.4 \\
$\quad$ Male & 20.9 & 19.9 & 13.9 & 16.3 & 16.7 \\
$\quad$ GDP per capita, PPP & 26.820 & 26.428 & 8.490 & 6.366 & 3.553 \\
USD ** & & & & & \\
\hline
\end{tabular}

*Source: World population ageing 2007. New York: United Nations, Population Division.

** Source: Development in an ageing world: World economic and social survey 2007. New York: United Nations, Department of Economic and Social Affairs.

Note. The Gross Domestic Product (GDP) is the value of all final goods and services produced within a nation in a given year. Purchasing power parity (PPP) takes into account the relative cost of living and the inflation rates of the countries.

European regions differ strongly in the pace of ageing and in the options they can offer to support quality of life at advanced ages. Demographic and economic information on the five countries is presented in Table 1. France, Germany and Bulgaria are more aged than are Russia and Georgia. Life expectancy at birth is highest for French and German women (83.5 and 82.1, respectively), and more than 10 years shorter for women in Russia (71.8). Life expectancy at birth for Russian men is 58.7 years, about 17 to 18 years shorter than for their peers in France and Germany. The main reason for the relatively low male life expectancy in the East European countries is the high mortality among men under the age of 60. Average remaining life expectancy at age 60 is lower for both sexes in Russia, Bulgaria and Georgia compared to France and Germany. The bottom line of Table 1 shows sharp differences between the European regions in economic welfare: purchasing power parity is considerably higher in the selected West European countries than in the selected East European countries. 


\subsection{Measuring instruments}

\subsubsection{Dependent variable}

Loneliness is measured using the 6-item version of the De Jong Gierveld Loneliness Scale (De Jong Gierveld and Van Tilburg 2006, 2010). The scale encompasses three negatively formulated items ("I experience a general sense of emptiness", "I miss having people around" and "Often, I feel rejected") and three positively formulated items ("There are plenty of people that I can lean on in case of trouble", "There are many people that I can count on completely" and "There are enough people that I feel close to"). None of the items refer directly to loneliness. The items have three response categories: "no", "more or less", and "yes". The item response model of Rasch was applied when the scale was developed: scale scores were based on dichotomous item scores with the answer "more or less" always indicating loneliness. Following the developers' guidelines, the loneliness scale score is computed by counting neutral and positive answers ("more or less", "yes") to the negatively formulated items and neutral and negative answers ("no" and "more or less") to the positively formulated items, resulting in scores ranging from 0 to 6 (intensely lonely). Loneliness scale scores were not computed when item scores were missing. (For more information about the scale and the scoring procedures see the Appendix). The scale has proven to be reliable and valid for each of the countries under investigation (De Jong Gierveld and Van Tilburg, 2010). Scale reliability (as measured by Cronbach's alpha or rho) usually falls in the 0.80 to 0.90 range. The homogeneity of the scale varies across studies, with Loevinger's $H$ typically in the 0.30 to 0.50 range, which is sufficient, but not very strong. Van Tilburg and De Leeuw (1991) took data from six surveys and re-analysed them to investigate the robustness of the scale (defined as invariance of item nonresponse, inter-item (scale) homogeneity, person scalability, item p-values and scale means). The loneliness scale met the psychometric requirements of item non-response, scale homogeneity and person scalability, allowing the use of the scale in linear regression analyses.

\subsubsection{Explanatory variables}

Living arrangement. Information is available about whether the respondent lives alone, and if not, about the persons living in the same household. We used the United Nations classification (United Nations Department of Economic and Social Affairs/Population Division 2005) to construct living arrangement categories. That classification defines coresidence as living with at least one married child or with at least one child aged 25 
or older, under the assumption that such a living arrangement responds to the needs of parents rather than of the children. We used the age of 25 years as parameter for differentiating between living arrangements: (a) living alone, (b) couple-only household, (c) single, with one or more children aged 25 or over (and others), (d) partnered, with one or more children aged 25 or over (and others), (e) single, with others, and (f) partnered, with others. We refer to categories (c) and (d) as coresident. Older persons in categories (e) and (f) were excluded from the multivariate analyses, given their small numbers in both the East and West European countries (see Table 2). The low prevalence of types (c) and (d) in France and Germany meant that we were able to consider coresidence for Bulgaria, Russia, and Georgia only.

Intergenerational support. It is customary to use dichotomous variables in latent class analyses of intergenerational relationships (Dykstra and Fokkema 2011; Hogan, Eggebeen and Clogg 1993; Silverstein and Bengtson 1997; Silverstein et al. 2010). Though dichotomization suggests a loss of information, it ensures having a manageable number of cells for the latent class analyses. Eight items served as the basis for the construction of a typology of intergenerational support: help with household tasks (including childcare) given to coresident children ( $1=$ usually or always); help with household tasks given to non-resident children ( 1 = regular help in the past 12 months); help with household tasks received from non-resident children ( 1 = regularly received); help with childcare given to non-resident children $(1=$ at least once in the past 12 months); personal care received from coresident and non-resident children $(1=$ at least once in the past 12 months); personal care given to coresident and non-resident children ( 1 = at least once in the past 12 months); paid household help $(1=$ regularly pay someone); get-togethers with non-resident children $(1=$ at least weekly or more often).

\subsubsection{Control variables}

Several background characteristics representing possible cross-national differences were included as controls. General health status was based on the question "How is your health in general?" with answer categories 1 = very good, $2=$ good, $3=$ fair, $4=$ bad and 5 = very bad. Socioeconomic position was based on the question: "Thinking of your household's total monthly income, is your household able to make ends meet?" with answer categories ranging from $1=$ very easily to $6=$ with great difficulty. The number of children alive was also taken into consideration.

Furthermore, gender, measured as $0=$ male, $1=$ female, and age, a continuous variable running from 60 to 80 , were included in the analyses. 


\subsection{Analyses}

Latent class analysis (LCA) in Mplus (Muthén and Muthén 1998-2010) was applied to construct the typology of intergenerational support. Separate typologies were developed for (a) coresiding respondents in Bulgaria, Russia, and Georgia, (b) respondents in independent households in Bulgaria, Russia, and Georgia, and (c) respondents in independent households in France and Germany. As noted earlier, a typology was not developed for coresiding respondents in France and Germany because the number of cases was too small. The typologies are typical scoring patterns for the eight items representing upward support, downward support, and get-togethers.

We used Analysis of Variance (ANOVA) and linear regression analyses to examine mean differences in loneliness by region (Eastern or Western Europe), living arrangement and intergenerational support type. The multivariate analyses were based on datasets in which respondents were classified according to their most likely latent class membership. In using linear regression analyses we tested for violations of assumptions. None were found: tolerance coefficients were good (.80 or more) and Normal P-P plots of regression standardized residuals showed no deviation or minor deviation from the expected cumulative probability.

\section{Results}

\subsection{Background characteristics}

As Table 2 shows, the percentage of older adults reporting poor health is higher in the East European countries than in the West European countries. The proportion reporting having difficulty making ends meet is also higher in Russia, Bulgaria, and Georgia compared to France and Germany. Clear East-West contrasts in family size do not emerge. Older adults in France and Georgia have the highest mean number of living children. Average household size is higher in the East European countries than in the West European countries. In Western Europe, a larger proportion lives alone or as a member of a couple, and a smaller proportion lives with adult children. 
Table 2: $\quad$ Sample characteristics

\begin{tabular}{|c|c|c|c|c|c|}
\hline & France & Germany & Russia & Bulgaria & Georgia \\
\hline Response rate GGS, wave 1 (\%) & 66.3 & 55.4 & 44.8 & 74.9 & 71.5 \\
\hline Sample size GGS, wave 1 & 10,069 & 9,604 & 11,261 & 12,828 & 10,000 \\
\hline $\begin{array}{l}\text { Sample size, respondents aged } \\
60 \text { and over }\end{array}$ & 2541 & 2630 & 2823 & 2496 & 2266 \\
\hline \multicolumn{6}{|l|}{$\begin{array}{l}\text { Characteristics of respondents aged } \\
60 \text { and over: }\end{array}$} \\
\hline$\%$ female & 55.2 & 50.0 & 69.4 & 50.1 & 60.2 \\
\hline Mean age & 68.7 & 68.3 & 68.9 & 68.1 & 69.2 \\
\hline$\%$ in fair or (very) bad health & 46.9 & 49.0 & 94.8 & 71.3 & 92.7 \\
\hline $\begin{array}{l}\% \text { stating that household has (great) } \\
\text { difficulties making ends meet }\end{array}$ & 13.3 & 6.5 & 64.8 & 73.4 & 76.0 \\
\hline Mean number of children & 2.24 & 1.71 & 1.80 & 1.81 & 2.36 \\
\hline Mean household size & 1.71 & 1.75 & 1.96 & 2.36 & 3.43 \\
\hline \multicolumn{6}{|l|}{ Living arrangement: } \\
\hline Living alone & 37.8 & 35.2 & 39.3 & 20.7 & 16.9 \\
\hline Couple only & 52.7 & 55.6 & 31.6 & 46.1 & 21.5 \\
\hline $\begin{array}{l}\text { No partner, with child(ren) aged } 25 \\
\text { or over (and others) }\end{array}$ & 2.3 & 1.7 & 13.1 & 9.6 & 21.4 \\
\hline $\begin{array}{l}\text { With partner, with child(ren) aged } 25 \\
\text { or over (and others) }\end{array}$ & 3.0 & 3.5 & 7.5 & 16.4 & 30.9 \\
\hline No partner, with others & 1.8 & 1.1 & 4.9 & 2.9 & 4.1 \\
\hline With partner, with others & 2.3 & 2.8 & 3.6 & 4.4 & 5.2 \\
\hline
\end{tabular}

Source: GGS, wave 1

\subsection{Typology of intergenerational support}

Table 3 reports model fit statistics for the latent class analyses of intergenerational support. Model fit tests indicated that a three-class solution fitted the data for coresiding respondents in the East European countries best, whereas a four-class solution fitted the data for the respondents in independent households in East European and West European countries best. Information on the intergenerational support types is presented in Table 4, for respondents in Eastern Europe (coresident and independently living respondents, respectively) and Western Europe (only for the independently living respondents). Given the importance of living without or with partner, this differentiation is also taken into account in Table 4. The resulting typologies have both 
shared characteristics and unique features. Shared characteristics are recognizable in Table 4 as grouped in the same column.

Table 3: Model fit for the selected number of classes in the latent class analyses; men and women aged 60-79 years with living children.

\begin{tabular}{|c|c|c|c|c|c|}
\hline & Number & Dfa & L2 b & p-value & $\mathrm{BICc}$ \\
\hline Coresidence, Eastern Europe & 3 & 229 & 180.771 & 0.99 & 18379.4 \\
\hline Independent household, Eastern Europe & 4 & 96 & 46.877 & 1.00 & 20916.6 \\
\hline Independent household Western Europe & 4 & 96 & 51.255 & 1.00 & 20168.5 \\
\hline
\end{tabular}

a $\mathrm{Df}=$ degrees of freedom.

b L2 = Likelihood ratio statistic.

c $B I C=$ Bayesian Information Criterion.

Source: GGS, wave 1.

Table 4: Distribution of six intergenerational support types (in \%); men and women aged 60-79 years with children (Source: GGS, wave 1)

\begin{tabular}{|c|c|c|c|c|c|c|c|}
\hline & $\begin{array}{l}\text { Low likelihood } \\
\text { of support } \\
\text { exchanges and } \\
\text { get-togethers: }\end{array}$ & $\begin{array}{l}\text { High likelihood } \\
\text { of upward } \\
\text { personal care: }\end{array}$ & $\begin{array}{l}\text { High likelihood } \\
\text { of upward } \\
\text { practical } \\
\text { support: }\end{array}$ & $\begin{array}{l}\text { High likelihood } \\
\text { downward } \\
\text { support, } \\
\text { moderate } \\
\text { likelihood get- } \\
\text { togethers: } \\
\text { Type } 4\end{array}$ & $\begin{array}{l}\text { High likelihood } \\
\text { downward } \\
\text { support, } \\
\text { moderate } \\
\text { likelihood } \\
\text { upward } \\
\text { support: } \\
\text { Type } 5\end{array}$ & $\begin{array}{l}\text { High likelihood } \\
\text { downward } \\
\text { support and } \\
\text { weekly get- } \\
\text { togethers: } \\
\text { Type } 6\end{array}$ & $\mathbf{N}$ \\
\hline \multicolumn{8}{|l|}{$\begin{array}{l}\text { Coresidence, } \\
\text { Eastern Europe }\end{array}$} \\
\hline No partner & 35 & & 5 & 61 & & & 1085 \\
\hline With partner & 31 & & 2 & 67 & & & 1304 \\
\hline \multicolumn{8}{|c|}{$\begin{array}{l}\text { Independent household } \\
\text { Eastern Europe }\end{array}$} \\
\hline No partner & 53 & 2 & 11 & 35 & & & 1642 \\
\hline With partner & 56 & 1 & 5 & 39 & & & 2336 \\
\hline \multicolumn{8}{|c|}{$\begin{array}{l}\text { Independent household, } \\
\text { Western Europe }\end{array}$} \\
\hline No partner & 58 & & & 27 & 0.7 & 14 & 1369 \\
\hline With partner & 57 & & & 28 & 0.2 & 16 & 2417 \\
\hline
\end{tabular}

The three types for East European older adults in coresident households are: a low likelihood of upward and downward exchanges of support together with a low likelihood of weekly get-togethers with adult children living outside the home (type 1), a high likelihood of receiving help with household tasks (practical support) from both 
resident and non-resident children together with a low likelihood of other exchanges, including get-togethers (type 3), and a high likelihood of practical help to both resident and non-resident children together with a moderate likelihood of weekly get-togethers (type 4). Type 4 is most frequent: it is the most likely latent class for over $60 \%$ of respondents, both for respondents without and with partner in the household. Type 3 is least frequent: it is the most likely latent class for under $5 \%$ of respondents. Clearly, the East European older adults living with their children are more likely to be providers of support to their offspring than receivers. This pattern is observed regardless of whether a partner is also a member of the coresident household.

Four types of intergenerational support emerged for the East European older adults living independently. Three are similar to types observed for the coresident in the selected Eastern European countries: a low likelihood of upward and downward exchanges of support together with a low likelihood of weekly get-togethers with adult children living outside the home (type 1), a high likelihood of receiving help with household tasks from both resident and non-resident children together with a low likelihood of other exchanges including get-togethers (type 3), and a high likelihood of practical help to both resident and non-resident children together with a moderate likelihood of weekly get-togethers (type 4). Type 2, characterized by a high likelihood of receiving personal care from a non-resident child, is unique to the East European older adult living independently. However, type 2 is the most likely type for only a fraction of respondents in this group (around 1\%). Type 1 is most likely for about $50 \%$ of older adults in independent households in the Eastern European countries in the dataset, both for respondents without and with partner in the household. Again we see a greater likelihood to be involved in downward transfers (over 35\%) than in upward transfers (around 10\%).

Intergenerational exchanges of the West European older adults living independently fall into four classes. Two of these were also observed for the East Europeans: a low likelihood of upward and downward exchanges of support together with a low likelihood of weekly get-togethers with adult children living outside the home (type 1), and a high likelihood of practical help to both resident and non-resident children together with a moderate likelihood of weekly get-togethers (type 4). Type 1 is the most likely for about $60 \%$ of independently living older adults in the selected West European countries, whereas type 4 is the most likely for about $25 \%$. The prevalence of type 5, characterized by both upward and downward exchanges, is low: less than $1 \%$. Finally, type 6, characterized by both downward support and weekly get-togethers is the most likely for about $15 \%$ of respondents in this group. Types 5 and 6 are unique to the older adults in Western Europe living in independent households. As before, we see a greater likelihood to be involved in support given to adult children (about 40\%) than in support received from adult children (about 1\%). 


\subsection{Loneliness}

Mean loneliness scores for older adults differ significantly between countries ( $\mathrm{F}=$ $522,869 \mathrm{df}=4 \mathrm{p}<.000$ ). France and Germany are relatively low on loneliness, with mean scores of 1.61 and 1.58 respectively, both below the 2-level, that is the threshold differentiating between the not lonely (scores 0,1 ) and the moderate or intensely lonely (2-6). In the Eastern European countries mean loneliness is above 2, with intermediate levels for Russia (2.65) and Bulgaria (3.17), and the highest mean level for Georgia (3.66). Table 5 shows mean levels of loneliness by region, living arrangement, and intergenerational support type.

Consistent with Hypothesis 1, results show that older persons living alone are most lonely on average (3.60 in the East European countries, 2.00 in the West European countries), followed by those living with adult children (3.42 in the East European countries; no mean score for the West European countries given the small number of older adults in coresident households). Those living with a partner are least lonely on average (2.85 in the East European countries; 1.36 in the West European countries). We find no support for Hypothesis 2, which posited that the difference in loneliness between older adults living with a partner and those living alone would be greater in the East European countries than in the West European countries. Hypothesis 3 could not be put to the test given the low prevalence of coresidence in France and Germany.

According to Hypothesis 4, older adults not engaged in exchanges with their adult children should have the highest mean loneliness scores. Findings show otherwise. Older adults who are primarily on the receiving end are most lonely (type 3 for coresident household members in East Europe, type 2 for independent living older adults in East Europe, but not type 3 for independent living older adults in East Europe). Older adults with a low likelihood of support exchanges and get-togethers (type 1, both in East and in West Europe, for those in co-residence and for independent living older adults) have intermediate levels of loneliness as do those engaged in both upward and downward exchanges (type 5). Note, however, that the latter type has a low prevalence. Older adults who are primarily on the giving side (types 4, and 6) have the lowest levels of loneliness, which is consistent with Hypothesis 4. 
Table 5: Mean loneliness score (range 0, not lonely, - 6, intensely lonely) and SD by region, living arrangement, and intergenerational support type; men and women aged 60-79 years, with children (Source: GGS, wave 1)

\begin{tabular}{|c|c|c|c|c|c|c|c|c|}
\hline & $\begin{array}{l}\text { Low } \\
\text { kelihood of } \\
\text { support } \\
\text { exchanges } \\
\text { and get- } \\
\text { togethers: } \\
\text { Type } 1\end{array}$ & $\begin{array}{c}\text { High } \\
\text { likelihood of } \\
\text { upward } \\
\text { personal } \\
\text { care: } \\
\\
\text { Type 2 }\end{array}$ & $\begin{array}{c}\text { High } \\
\text { likelihood of } \\
\text { upward } \\
\text { practical } \\
\text { support: } \\
\\
\text { Type 3 }\end{array}$ & $\begin{array}{c}\text { High } \\
\text { likelihood } \\
\text { downward } \\
\text { support, } \\
\text { moderate } \\
\text { likelihood } \\
\text { get- } \\
\text { togethers: } \\
\text { Type 4 }\end{array}$ & $\begin{array}{c}\text { High } \\
\text { likelihood } \\
\text { downward } \\
\text { support, } \\
\text { moderate } \\
\text { likelihood } \\
\text { upward } \\
\text { support: } \\
\text { Type 5 } \\
\end{array}$ & $\begin{array}{c}\text { High } \\
\text { likelihood } \\
\text { downward } \\
\text { support and } \\
\text { weekly get- } \\
\text { togethers: } \\
\text { Type } 6\end{array}$ & $\mathbf{F}$ & Overall mean \\
\hline \multicolumn{9}{|l|}{$\begin{array}{l}\text { Coresidence, } \\
\text { Eastern Europe }\end{array}$} \\
\hline No partner & $\begin{array}{c}3.49 \\
(1.81)\end{array}$ & & $\begin{array}{c}4.68 \\
(1.52)\end{array}$ & $\begin{array}{c}3.29 \\
(1.86)\end{array}$ & & & 0.962 & $\begin{array}{c}3.42 \\
(1.85)\end{array}$ \\
\hline With partner & $\begin{array}{c}3.19 \\
(1.69)\end{array}$ & & $\begin{array}{c}3.89 \\
(1.99)\end{array}$ & $\begin{array}{c}2.71 \\
(1.78)\end{array}$ & & & $4.311^{\star \star \star}$ & $\begin{array}{c}2.88 \\
(1.78)\end{array}$ \\
\hline \multicolumn{9}{|c|}{$\begin{array}{l}\text { Independent household, } \\
\text { Eastern Europe }\end{array}$} \\
\hline No partner, alone & $\begin{array}{c}3.92 \\
(1.88)\end{array}$ & $\begin{array}{l}-- \\
--\end{array}$ & $\begin{array}{c}3.18 \\
(2.09)\end{array}$ & $\begin{array}{c}3.24 \\
(1.97)\end{array}$ & & & $7.926^{\star \star \star}$ & $\begin{array}{l}3.60 \\
(1.97)\end{array}$ \\
\hline With partner, couple & le $\begin{array}{r}3.01 \\
(1.79)\end{array}$ & $\begin{array}{c}3.89 \\
(1.82)\end{array}$ & $\begin{array}{c}2.52 \\
(1.96)\end{array}$ & $\begin{array}{c}2.46 \\
(1.76)\end{array}$ & & & $10.963^{\star \star \star}$ & $\begin{array}{c}2.78 \\
(1.81)\end{array}$ \\
\hline \multicolumn{9}{|c|}{$\begin{array}{l}\text { Independent household, } \\
\text { Western Europe }\end{array}$} \\
\hline No partner, alone & $\begin{array}{c}2.31 \\
(1.88)\end{array}$ & & & $\begin{array}{c}1.72 \\
(1.76)\end{array}$ & $\begin{array}{l}-- \\
--\end{array}$ & $\begin{array}{l}1.24 \\
(1.38)\end{array}$ & $11.929^{* \star \star}$ & $\begin{array}{l}2.00 \\
(1.83)\end{array}$ \\
\hline $\begin{array}{l}\text { With partner, } \\
\text { couple }\end{array}$ & $\begin{array}{c}1.54 \\
(1.62)\end{array}$ & & & $\begin{array}{l}1.18 \\
(1.53)\end{array}$ & -- & $\begin{array}{l}1.06 \\
(1.29)\end{array}$ & $7.866^{\star \star \star}$ & 1.36 \\
\hline
\end{tabular}

${ }^{* \star *} \mathrm{p}<.000$

\subsection{East-West contrasts}

Table 6, which shows differences in loneliness by intergenerational support type, provides insight into regional differences in predictors of loneliness. Six parallel regression analyses were carried out. Four were based on the data from Eastern Europe: coresident and older adults without partners, co-resident and older adults with partners, older adults living alone, and older adults living as a couple. Two were based on the data from Western Europe: older adults living alone, and older adults living as a couple. In each of the six analyses, the type characterized by a low likelihood of exchanges of 
support and get-togethers served as the reference category. Control variables included: self-rated health, ability to make ends meet, the number of living children, sex, and age.

Table 6: Loneliness as predicted by intergenerational support type, living arrangement and partner status; men and women aged 60-79 years with children, in Eastern and Western Europe

\begin{tabular}{|c|c|c|c|c|c|c|c|c|c|c|c|c|}
\hline & \multicolumn{4}{|c|}{$\begin{array}{l}\text { Eastern Europe } \\
\text { coresidence }\end{array}$} & \multicolumn{4}{|c|}{$\begin{array}{c}\text { Eastern Europe } \\
\text { independent living }\end{array}$} & \multicolumn{4}{|c|}{$\begin{array}{l}\text { Western Europe } \\
\text { independent living }\end{array}$} \\
\hline & \multicolumn{2}{|c|}{ no partner } & \multicolumn{2}{|c|}{ with partner } & \multicolumn{2}{|c|}{ alone } & \multicolumn{2}{|c|}{ couple } & \multicolumn{2}{|c|}{ alone } & \multicolumn{2}{|c|}{ couple } \\
\hline & B & $\beta$ & B & $\beta$ & B & $\beta$ & B & $\beta$ & B & $\beta$ & B & $\beta$ \\
\hline $\begin{array}{l}\text { Constant } \\
\text { Intergenerational support type } \\
\text { 1, low likelihood support } \\
\text { exchange and get- } \\
\text { togethers(ref.) }\end{array}$ & 2.262 & & 2.312 & & 3.676 & & 1.964 & & 2.740 & & 1.262 & \\
\hline $\begin{array}{l}\text { 3, high likelihood upward } \\
\text { practical support }\end{array}$ & .80 & $.09^{\star \star}$ & .28 & .02 & & & & & & & & \\
\hline $\begin{array}{l}\text { 4, high likelihood } \\
\text { downward support, } \\
\text { moderate likelihood } \\
\text { get-togethers }\end{array}$ & -.11 & -.03 & -.26 & $-.07 *$ & & & & & & & & \\
\hline $\begin{array}{l}\text { 1, low likelihood support } \\
\text { exchange and get- } \\
\text { togethers (ref.) }\end{array}$ & & & & & & & & & & & & \\
\hline $\begin{array}{l}\text { 2, high likelihood upward } \\
\text { personal care }\end{array}$ & & & & & -.13 & -.01 & .42 & .02 & & & & \\
\hline $\begin{array}{l}\text { 3, high likelihood upward } \\
\text { practical support }\end{array}$ & & & & & -.72 & $-.12^{\star \star \star}$ & -.66 & $-.08^{\star \star \star}$ & & & & \\
\hline $\begin{array}{l}\text { 4, high likelihood } \\
\text { downward support, } \\
\text { moderate likelihood } \\
\text { get-togethers }\end{array}$ & & & & & -.50 & $-.12^{\star \star \star}$ & -.47 & $-.13^{\star \star \star}$ & & & & \\
\hline $\begin{array}{l}\text { 1, low likelihood support } \\
\text { exchange and get- } \\
\text { togethers (ref.) } \\
\text { 4, high likelihood }\end{array}$ & & & & & & & & & & & & \\
\hline $\begin{array}{l}\text { downward support, } \\
\text { moderate likelihood } \\
\text { get-togethers }\end{array}$ & & & & & & & & & -.58 & $-.14^{\star \star \star}$ & -.35 & $-.10^{\star \star \star}$ \\
\hline 5, high likelihood & & & & & & & & & & & & \\
\hline $\begin{array}{l}\text { downward, moderate } \\
\text { likelihood upward support }\end{array}$ & & & & & & & & & -.89 & -.04 & .03 & .00 \\
\hline $\begin{array}{l}\text { 6, high likelihood } \\
\text { downward support and } \\
\text { get-togethers }\end{array}$ & & & & & & & & & -.99 & $-.19^{\star \star \star}$ & -.42 & $-.10^{\star \star \star}$ \\
\hline
\end{tabular}


Table 6: (Continued)

\begin{tabular}{|c|c|c|c|c|c|c|c|c|c|c|c|c|}
\hline & \multicolumn{4}{|c|}{$\begin{array}{l}\text { Eastern Europe } \\
\text { Coresidence }\end{array}$} & \multicolumn{4}{|c|}{$\begin{array}{c}\text { Eastern Europe } \\
\text { independent living }\end{array}$} & \multicolumn{4}{|c|}{$\begin{array}{c}\text { Western Europe } \\
\text { independent living }\end{array}$} \\
\hline & \multicolumn{2}{|c|}{ no partner } & \multicolumn{2}{|c|}{ with partner } & \multicolumn{2}{|c|}{ alone } & \multicolumn{2}{|c|}{ couple } & \multicolumn{2}{|c|}{ alone } & \multicolumn{2}{|c|}{ couple } \\
\hline & B & $\beta$ & B & $\beta$ & B & $\beta$ & B & $\beta$ & B & $\beta$ & B & $\beta$ \\
\hline \multicolumn{13}{|l|}{ Control variables } \\
\hline $\begin{array}{l}\text { Subjective health (very good } \rightarrow \\
\text { very bad) }\end{array}$ & .27 & $.12^{\star \star \star}$ & .32 & $.16^{\star \star \star}$ & .30 & $.13^{\star \star \star}$ & .43 & $.20^{\star \star \star}$ & .42 & $.21^{\star \star \star}$ & .30 & $.16^{\star \star \star}$ \\
\hline $\begin{array}{l}\text { Can household make ends meet? } \\
\text { (More or less easily } \\
\rightarrow \text { with great difficulty) }\end{array}$ & .49 & $.26^{\star \star \star}$ & .32 & $.18^{\star \star \star}$ & .47 & $.29^{\star \star \star}$ & .35 & $.20^{\star \star \star}$ & .22 & $.15^{\star \star \star}$ & .21 & $.14^{\star \star \star}$ \\
\hline Number of living children & -.03 & -.02 & -.11 & $-.07^{\star}$ & -.02 & -.01 & -.02 & -.01 & -.09 & $-.07^{\star \star}$ & -.14 & $-.11^{\star \star \star}$ \\
\hline Sex (Male-Female) & -.04 & -.01 & -.13 & -.04 & -.87 & $-.17^{\star \star \star}$ & -.12 & -.03 & -.12 & -.03 & .19 & $.06^{\star \star}$ \\
\hline Age $(60 \rightarrow 79)$ & .02 & .06 & .01 & .03 & .02 & $.06^{\star}$ & .02 & $.04^{\star}$ & -.00 & -.01 & .01 & .02 \\
\hline$N$ & \multicolumn{2}{|c|}{1092} & \multicolumn{2}{|c|}{1318} & \multicolumn{2}{|c|}{1637} & \multicolumn{2}{|c|}{2336} & \multicolumn{2}{|c|}{1370} & \multicolumn{2}{|c|}{2417} \\
\hline $\mathrm{R}^{2}$ adj. & \multicolumn{2}{|c|}{.114} & \multicolumn{2}{|c|}{.084} & \multicolumn{2}{|c|}{.120} & \multicolumn{2}{|c|}{.116} & \multicolumn{2}{|c|}{.123} & \multicolumn{2}{|c|}{.081} \\
\hline
\end{tabular}

Source: GGS, wave 1.

The data allow only a partial test of Hypothesis 5, which posits a weaker negative effect of get-togethers in the East European countries than in the West European countries. The hypothesis finds support insofar as West European older adults with a high likelihood of downward support and weekly get-togethers (type 6) are well protected against loneliness, particularly if they live alone. A straightforward comparison with the Eastern Europeans is not possible, given the absence of a comparable intergenerational support type. In both the East and West European countries, the type characterized by a high likelihood of downward transfers and a moderate likelihood of weekly get-togethers (type 4) emerged for older adults in independent households. Contrary to Hypothesis 5, associations between this intergenerational support type and loneliness are similar in the two European regions.

A proper test of Hypothesis 6 is not possible either, again because of the absence of comparable intergenerational support types in the East European and West European countries. Upward support is more likely in Russia, Bulgaria, and Georgia than in France and Germany. In the East European countries, a high likelihood of being on the receiving side contributes to greater loneliness among older adults in coresident households (type 3), but protects against loneliness among older adults living independently (type 3). Here we have evidence that the effect of support varies by living arrangement.

We encountered no problems testing Hypothesis 7, given that in both East and West European countries, there was a class of older adults in independent households with a high likelihood of downward support (type 4). Results are not in line with the 
hypothesis, however. We find no evidence that being primarily on the giving side increases the propensity for loneliness in the East European countries to a larger extent than in the West European countries. The magnitude of the coefficients is virtually identical in the two regional samples.

The associations between the control variables and loneliness show few surprises. Older adults who report poorer health tend to have higher levels of loneliness, regardless of their living arrangement and region of residence. Likewise, those whose households have difficulty in making ends meet tend to report greater loneliness. Having financial difficulties is more strongly associated with loneliness in the East European countries than in the West European countries. The number of children protects against loneliness in the West European countries, regardless of living arrangement. In the East European countries, the number of children protects against loneliness only for older adults who live with their partner and adult children. Sex and age show no consistent differences in loneliness across regions and living arrangements.

\section{Discussion}

The aim of this study was to investigate differences in older adult loneliness linked with living arrangements and intergenerational support. First, we went beyond the wellknown comparison of older adults living alone and those living as a couple, by also considering older adults in coresident households. Second, we went beyond the household by considering support exchanges both up and down generational lines with coresident and non-coresident children. Third, we went beyond an exclusive focus on West European countries by also considering selected East European countries.

Findings showed that older persons in Russia, Bulgaria, and Georgia tend to be lonelier than their peers in France and Germany. This East-West wellbeing differential is consistent with earlier work. Studies of life satisfaction, for example, have revealed lower wellbeing in former communist countries than among long-term members of the European Union (Delhey 2004). Carlson (1998) speaks about a striking East-West divide in self-perceived health. An issue of debate is whether cross-national differences reflect real differences or cultural differences in the way people rate their experiences (Bolle and Kemp 2009; Vuorisalmi et al. 2008). We lean towards the latter, given that the loneliness-measuring instrument used in the GGS has proven cross-national equivalence (De Jong Gierveld and Van Tilburg 2010). The reliability, validity and structural characteristics of the scale are of high quality and allow intercultural comparison. It is important to note that our study was based on data from only five countries. A proper comparison of East European and West European societies should of course be based on a larger number of countries. Although results have revealed only 
few and minor discrepancies between GGS estimates on one hand, and vital statistics on the other hand, we must draw attention to the possible bias from overrepresentation of childless women and underrepresentation of young adult children in the German sample.

Living arrangement differences in loneliness were as predicted: older adults living alone were generally most lonely, whereas older adults living with a partner were generally least lonely. This pattern was observed in both the East European and West European countries. Given the low prevalence of coresidence in France and Germany, we had to limit the analysis of links between living with adult children and loneliness to Russia, Bulgaria, and Georgia. Findings showed intermediate levels of loneliness for older parents in coresident households. Apparently, living with adult children provides some protection against loneliness, but not to the same degree as having a partner relationship.

To gain a better understanding of relationships with adult children, we examined the direction of supportive exchanges and the frequency of get-togethers, bringing these characteristics together in typologies of intergenerational support. The most frequently observed type, in both the Eastern and Western countries, was one with a low likelihood of intergenerational exchanges and weekly get-togethers. Apparently, when not facing a crisis, such as an elderly parent being ill and needing care or an adult child under personal duress, functional solidarity exists, but is not extensive in European families. The family typology developed by Hogan, Eggebeen and Clogg (1993) for the United States showed a similar result. Independence and allowing family members to live their own lives appear to be the norm. Family members step in, however, when the situation demands help and assistance. An intergenerational support type characterized by a high probability of help both upward and downward was highly unlikely. It did not emerge in the East European samples, and applied to less than one percent of older persons in the West European samples, Thus, in general, and as also reported by Dykstra and Fokkema (2011), an immediate reciprocity pattern of support exchange is not characteristic of relationships between parents and their adult children. Rather, support exchanges follow a life course pattern, with primarily downward transfers more likely up to advanced ages of the parent, and primarily upward transfers emerging in the latest phase of the parents' life. Findings showed a greater likelihood of being involved in support given to adult children than in support received from adult children. This pattern applied to both coresident households and independent households. The younger generation generally benefits (Kohli 2004; Kohli, Albertini and Künemund 2010). We would like to note that the low likelihood of primarily upward transfers might be attributable to the age range of respondents in the samples. The maximum age was 79 . Inclusion of the oldest old would probably result in a greater likelihood of upward transfers, given their higher health needs. 
The results on the direction of supportive exchanges shed light on mechanisms underlying coresidence. It is not solely the result of adult children taking frail parents into their homes to provide them with care and support. Rather, adult children and older parents might be members of the same household because the former have never left home. Contextual factors need to be taken into account, such as the availability and affordability of housing. In her description of East European circumstances, Robila (2004: 3) states: "The shortage of housing and high prices force young families to live, at least for several years, with their parents. This creates difficulties for young people wishing to own or rent an apartment independently, and places families under intolerable pressure and intergenerational tensions". Similar circumstances have been reported by Tarturri, De Santis and Seghieri (2008: 95) for Italy: “...a system that protects the elders too much (through generous pensions and social security systems) at the expense of the young generations, who therefore frequently need to rely on their families, even in adulthood”. Consequently, co-residing with grown up children is more frequently observed when the younger generation experiences setbacks on the job or marriage market (Mitchell 2005).

Contrary to expectations, older adults with a low likelihood of exchanges and gettogethers did not have the highest mean loneliness levels. Older adults who were primarily on the receiving side were most lonely, particularly if they were in coresident households. Older adults who were primarily on the giving side were generally least lonely. Findings are in line with altruism theory, which posits that giving to others is beneficial. As Rossi and Rossi (1990) have observed, parents very often maintain helping patterns long after the children have become adults. People do not drop the parent role as they age, and parents may feel concern and responsibility for children and grandchildren as long as they live (Herlofson and Hagestad 2012).

Drawing upon writings suggesting that older parents in Western Europe attach greater importance to autonomy and to the emotional qualities of relationships with adult children than parents in Eastern Europe, we had expected to find regional differences in living arrangements and support types as predictors of loneliness. The data showed otherwise. Thus, we found no support for the hypothesis that living alone would make older adults in the East European countries more vulnerable to loneliness than in the West European countries. Neither did we find that being primarily on the giving side less adequately protects against loneliness in the East European countries than in the West European countries. The strength of the associations between loneliness and the living arrangement and support type predictors was similar in the two regions. The regional differences in loneliness seem to be attributable to population composition rather than interaction effects where the importance of individual-level predictors varies between countries (Dykstra 2009). Note, however, that we were not always able to test hypotheses on differential effects in Eastern and Western Europe due 
to the absence of comparable family types in the two regions. Our study substantiates earlier work on the East-West divide in family patterns (Therborn 2004; Hajnal 1965).

Our study revealed significantly higher levels of older adult loneliness in East European countries than in West European countries, without a solid basis for explaining the differences. One of the limitations of the present investigation is the absence of information on general values, standards and attitudes concerning social wellbeing. To what extent are family relationships and friendships evaluated as necessary for social engagement? Another direction for future research concerns the role of public social security. To what extent is welfare state spending an incentive or disincentive for intergenerational transfers in families, and thus, albeit indirectly, a condition for the alleviation or development of loneliness?

The outcomes of this study have provided us with clear evidence that living arrangements and intergenerational support are of vital relevance to older adult loneliness. They also show that a better explanation of older adult loneliness is obtained if the direction of supportive exchanges with adult children is considered, than if only living arrangements are considered. It is important to note that the prevention and reduction of loneliness have repercussions beyond the social realm. Older adults who are well integrated socially are less prone to diseases and less likely to require health and care services (Berkman et al. 2000). As the World Health Organization (2002) has pronounced, policies and programs that promote social participation and connectedness are as important as those that improve physical health.

\section{Acknowledgments}

This paper was written in the context of MULTILINKS (How demographic changes shape intergenerational solidarity, well-being, and social integration: A multilinks framework), a program of research funded through the seventh framework program of the European Commission (grant number 217523). Earlier versions of this paper were presented at the Seminar on Family Support Networks and Population Ageing in Doha, Qatar, organized by the United Nations Programme on Ageing (June 3-4, 2009), the European Population Conference, Vienna (September 1-4, 2010) and at the Expert Group Meeting of the Programme on the Family of the United Nations in Doha, Qatar (March 3-4, 2011). The data for this paper were obtained from the GGP Data Archive (United Nations 2005). 


\section{References}

Adams, G., Anderson, S.L., and Adonu, J.K. (2004). The cultural grounding of closeness and intimacy. In: Mashek, D.J. and Aron, A. (eds.). Handbook of Closeness and Intimacy. Mahwah (New Jersey): Lawrence Erlbaum: 321-339.

Ajrouch, K., Akiyama, H., and Antonucci, T.C. (2007). Cohort differences in social relations among the elderly. In: Wahl, H.-W., Tesch-Roemer, C., and Hoff, A. (eds.). New Dynamics in old age: Individual, environmental and societal perspectives. New York: Baywood, Amityville: 43-63.

Albertini, M., Kohli, M., and Vogel, C. (2007). Intergenerational transfers of time and money in European families: Common patterns - different regimes? Journal of European Social Policy 17(4): 319-334. doi:10.1177/0958928707081068.

Attias-Donfut, D., Ogg, J., and Wolff, F. (2005). European patterns of intergenerational financial and time transfers. European Journal of Ageing 2(3): 161-173. doi:10. 1007/s10433-005-0008-7.

Batson, C.D. (1998). Altruism and prosocial behaviour. In: Gilbert, D.T., Fiske, S.T., and Lindzey, G. (eds.). The Handbook of Social Psychology. Volume 2. New York: McGraw-Hill: 282-316.

Bengtson, V.L. and Roberts, R.E.L. (1991). Intergenerational solidarity in aging families: An example of formal theory construction. Journal of Marriage and Family 53(4): 856-870. doi:10.2307/352993.

Berkman, L.F., Glass, T., Brissette, I., and Seeman,T.E. (2000). From social integration to health: Durkheim in the New Millennium. Social Science and Medicine 51(6): 843-857. doi:10.1016/S0277-9536(00)00065-4.

Bezrukov, V. and Foigt, N. (2002). Political, social and economic crises and living arrangements of older persons: the case of Ukraine. New York: UN Population Division.

Bolle, F. and Kemp, S. (2009). Can we compare life satisfaction between nationalities? Evaluating actual and imagined situations. Social Indicators Research 90(3): 397-408. doi:10.1007/s11205-008-9265-0.

Carlson, P. (1998). Self-perceived health in East and West Europe. Another European health divide. Social Science and Medicine 46(10): 1355-1366. doi:10.1016/ S0277-9536(97)10093-4. 
Chen, F. and Short, S.E. (2008). Household context and subjective well-being among the oldest old in China. Journal of Family Issues 29(10): 1379-1403. doi:10.1177/0192513X07313602.

Chodorow, N.J. (1978). The reproduction of mothering: Psychoanalysis and the sociology of gender. Berkeley: University of California Press.

Cohen, P.N. and Casper, L.M. (2002). In whose home? Multigenerational families in the United States, 1998-2000. Sociological Perspectives 45(1): 1-20. doi:10.152 5/sop.2002.45.1.1.

Cohen, S. and Wills, T.A. (1985). Stress, social support, and the buffering hypothesis. Psychological Bulletin 98(2): 310-357. doi:10.1037/0033-2909.98.2.310.

Cornwell, E.Y. and Waite, L.J. (2009). Measuring social isolation among older adults using multiple indicators from the NSHAP Study. Journal of Gerontology: Social sciences 64B(supplement 1): i38-i46. doi:10.1093/geronb/gbp037.

De Jong Gierveld, J., Broese van Groenou, M., Hoogendoorn, A.W., and Smit, J.H. (2009). Quality of marriages in later life and emotional and social loneliness. Journal of Gerontology: Social Sciences 64B(4): 497-506. doi:10.1093/geronb/ gbn043.

De Jong Gierveld, J. and Van Tilburg, T. (1999). Living arrangements of older adults in the Netherlands and Italy: Coresidence values and behaviour and their consequences for loneliness. Journal of Cross-Cultural Gerontology 14(1): 1-24. doi:10.1023/A:1006600825693.

De Jong Gierveld, J. and Van Tilburg, T. (2006). A six-item scale for overall, emotional and social loneliness: Confirmative tests on new survey data. Research on Aging 28(5): 582-598. doi:10.1177/0164027506289723.

De Jong Gierveld, J. and Van Tilburg, T. (2010). The De Jong Gierveld Short Scales for emotional and social loneliness: Tested on data from seven countries in the UN Generations and Gender Surveys. European Journal of Ageing 7(2): 121130. doi:10.1007/s10433-010-0144-6.

Delhey, J. (2004). Life satisfaction in an enlarged Europe. Luxembourg: Office for Official Publications of the European Communities.

Dykstra, P.A. (1993). The differential availability of relationships and the provision and effectiveness of support to older adults. Journal of Social and Personal Relationships 10(3): 355-370. doi:10.1177/0265407593103004. 
Dykstra, P.A. (2006). Off the beaten track: Childlessness and social integration in late life. Research on Aging 28(6): 749-767. doi:10.1177/0164027506291745.

Dykstra, P.A. (2009). Older adult loneliness: Myths and realities. European Journal of Ageing 6(2): 91-100. doi:10.1007/s10433-009-0110-3.

Dykstra, P.A. and De Jong Gierveld, J. (2004). Gender and marital-history differences in emotional and social loneliness among Dutch older adults. Canadian Journal of Aging / La Revue canadienne du vieillissement 23(2): 141-155. doi:10.1353/cja.2004.0018.

Dykstra, P.A. and Fokkema, T. (2011). Relationships between parents and their adult children: A West European typology of late-life families. Ageing \& Society 31(4): 545-569. doi:10.1017/S0144686X10001108.

Dykstra, P.A. and Hagestad, G.O. (2007). Roads less taken: Developing a nuanced view of older adults without children. Journal of Family Issues 28(10): 1275-1310. doi:10.1177/0192513X07303822.

Emerson, R. (1976). Social exchange theory. Annual Review of Sociology 2: 335-362. doi:10.1146/annurev.so.02.080176.002003.

Finch, J. (1995). Responsibilities, obligations and commitments. In: Allen, I. and Perkins, E. (eds.). The future of family care for older people. London: HMSO: 51-64.

Furstenberg, F.F. (2005). Banking on families: How families generate and distribute social capital. Journal of Marriage and Family 67(4): 809-821. doi:10.1111/j. 1741-3737.2005.00177.x.

Grundy, E., Murphy, M., and Shelton, N. (1999). Looking beyond the household: Intergenerational perspectives on living kin and contacts with kin in Great Britain. Population Trends 97: 19-27.

Hagestad, G.O. (2000). Adults' intergenerational relationships. In: Generations and Gender Programme: Exploring future research and data collection options. New York/Geneva: United Nations: 125-143.

Hagestad, G.O. and Uhlenberg, P. (2006). Should we be concerned about age segregation? Some theoretical and empirical explorations. Research on Aging 28(6): 638-653. doi:10.1177/0164027506291872.

Hajnal, J. (1965). European marriage patterns in perspective. In: Glass, D.V. and Everlsey, D.E.C. (eds.). Population in history. Chicago: Aldine: 101-143. 
Hank, K. (2007). Proximity and contact between older parents and their children. A European comparison. Journal of Marriage and Family 69(1): 159-173. doi:10.1 111/j.1741-3737.2006.00351.x.

Hawkley, L.C., Hughes, M.E., Waite, L.J., Masi, C.M., Thisted, R.A., and Cacioppo, J.T. (2008). From social structural factors to perceptions of relationship quality and loneliness: The Chicago health, aging, and social relations study. Journal of Gerontology: Social Sciences 63B(6): 375-384. doi:10.1093/geronb/63.6.S375.

Herlofson, K. and Hagestad, G.O. (2012). Transformations in the role of grandparentsacross welfare states. In: Arber, S. and Timonen, V. (eds.). Contemporary grandparenting: Changing family relationships in global contexts. Bristol: The Policy Press: 25-51.

Höllinger, F. and Haller, M. (1990). Kinship and social networks in modern societies: A cross-cultural comparison among seven nations. European Sociological Review 6(2): 103-124.

Hogan, D.P., Eggebeen, D.J., and Clogg, C.C. (1993). The structure of intergenerational exchanges in American families. American Journal of Sociology 98(6): 14281458. doi:10.1086/230194.

Jylhä, M. and Jokela, J. (1990). Individual experiences as cultural: A crosscultural study on loneliness among the elderly. Ageing \& Society 10(2): 295-315.

Kahana, E. and Young, R. (1990). Clarifying the caregiving paradigm: Challenges for the future. In: Biegel, D.E. and Blum, A. (eds.). Aging and caregiving: Theory, research and policy. London: Sage: 76-97.

Kohli, M. (2004). Intergenerational transfers and inheritance: A comparative view. Annual Review of Gerontology and Geriatrics 24(1): 266-289.

Kohli, M., Albertini, M., and Künemund, H. (2010). Linkages among family generations: Evidence from comparative family research. In: Heady, P. and Kohli, M. (eds.). Family, kinship and state in contemporary Europe. Volume 3: Perspectives on theory and policy. Frankfurt: Campus Verlag: 225-248.

Korporaal, M., Broese van Groenou, M., and Van Tilburg, T.G. (2008). Effects of own and spousal disability on loneliness among older adults. Journal of Aging and Health 20(3): 306-325. doi:10.1177/0898264308315431.

Krause, N., Newsom, J.T., and Rook, K.S. (2008). Financial strain, negative social interaction, and self-rated health: Evidence from two United States nationwide 
longitudinal surveys. Ageing \& Society 28(7): 1001-1023. doi:10.1017/S01446 86X0800740X.

Kreyenfeld, M., Hornung, A., Kubisch, K., and Jaschinski, I. (2010). Fertility and union histories from German GGS data: Some critical reflections. Rostock: Max Planck Institute for Demographic Research (MPIDR Working Paper; WP 2010023). http://www.demogr.mpg.de/papers/working/wp-2010-023.pdf .

Levitzki, N. (2009). Parenting of adult children in an Israeli sample: Parents are always parents. Journal of Family Psychology 23(2): 226-235. doi:10.1037/a0015218.

Mitchell, B.A. (2005). The boomerang age: Transitions to adulthood in families. New Brunswick, NJ: Transaction Publishers.

Muthén, L.K. and Muthén, B.O. (1998-2010). Mplus user's guide. Sixth edition. Los Angeles, CA: Muthén \& Muthén.

Neels, K., De Winter, T., and Vermant, G. (2011). Quality of demographic data in GGS wave 1. (Paper presented at the First Generations and Gender Programme User Conference, Budapest, Hungary, May 23-24 2011).

Nolan, M., Grant, G., and Keady, J. (1996). Understanding family care: A multidimensional model of caring and coping. Buckingham, UK: Open University Press.

Oppong, C. (2006). Familial roles and social transformations: Older men and women in Sub-Saharan Africa. Research on Aging 28(6): 654-668. doi:10.1177/016402750 6291744.

Perlman, D. and Peplau, L.A. (1981). Toward a social psychology of loneliness. In: Gilmour, R. and Duck, S. (eds.). Personal relationships 3: Personal relationships in disorder. London: Academic Press: 31-43.

Petrov, I.C. (2007). The elderly in a period of transition: Health, personality and social aspects of adaptation. Annals of the New York Academy of Sciences 1114: 300309. doi:10.1196/annals.1396.041.

Pinquart, M. (2003). Loneliness in married, widowed, divorced, and never-married older adults. Journal of Social and Personal Relationships 20(1): 31-53. doi:10.1177/02654074030201002.

Pinquart, M. and Sörensen, S. (2001). Influences on loneliness in older adults: A metaanalysis. Basic and Applied Social Psychology 23(4): 245-266. doi:10.1207/S15324834BASP2304_2. 
Robila, M. (2004). Families in Eastern Europe: Context, Trends and Variations. In: Robila, M. (ed.). Families in Eastern Europe. Amsterdam: Elsevier: 1-14. doi:10.1016/S1530-3535(04)05001-0.

Rokach, A., Orzeck, T., Cripps, J., Lackovic-Grgin, K., and Penezic, Z. (2001). The effects of culture on the meaning of loneliness. Social Indicators Research 53(1): 17-31. doi:10.1023/A:1007183101458.

Rosenmayr, L. and Köckeis, E. (1963). Propositions for a sociological theory of ageing and the family. International Social Science Journal 15(3): 410-426.

Rosow, I. (1967). Social integration of the aged. New York: The Free Press.

Rossi, A.S. and Rossi, P.H. (1990). Of human bonding, parent-child relations across the life course. New York: Aldine de Gruyter.

Schröder-Butterfill, E. (2004). Inter-generational family support provided by older people in Indonesia. Ageing \& Society 24(4): 497-530. doi:10.1017/S0144686X0 400234X.

Silverstein, M. and Bengtson, V.L. (1997). Intergenerational solidarity and the structure of adult-parent relationships in American families. American Journal of Sociology 103(2): 429-460. doi:10.1086/231213.

Silverstein, M., Gans, D., Lowenstein, A., Giarrusso, R., and Bengtson, V.L. (2010). Older parent-child relationships in six developed nations: Comparisons at the intersection of affection and conflict. Journal of Marriage and Family 72(4): 1006-1021. doi:10.1111/j.1741-3737.2010.00745.x.

Smits, A., Van Gaalen, R.I., and Mulder, C.H. (2010). Parent-child coresidence: Who moves in with whom and for whose needs? Journal of Marriage and Family 72(4): 1022-1033. doi:10.1111/j.1741-3737.2010.00746.x.

Stevens, N. and Westerhof, G.J. (2006). Marriage, social integration and loneliness in the second half of life: A comparison of Dutch and German men and women. Research on Aging 28(6): 713-729. doi:10.1177/0164027506291747.

Sundström, G., Fransson, E., Malmberg, B., and Davey, A. (2009). Loneliness among older Europeans. European Journal of Ageing 6(4): 267-275. doi:10.1007/s10 433-009-0134-8.

Tanturri, M.L., De Santis, G., and Seghieri, C. (2008). Economic well-being in old age in Italy: does having children make a difference? Genus 64(1-2), 75-99. 
Thelen, T. (2006). Law and mutual assistance in families: A comparison of socialist legacies in Hungary and Eastern Germany. Journal of Legal Pluralism and Unofficial Law 53/54: 177-207.

Therborn, G. (2004). Between sex and power: Family in the world, 1900-2000. London: Routledge.

Tomassini, C., Glaser, K., Wolf, D., Broese van Groenou, M., and Grundy, E. (2004). Living arrangements among older people: An overview of trends in Europe and the USA. Population Trends 115: 24-34.

Treas, J. and Cohen, P.N. (2006). Maternal coresidence and contact: Evidence from cross-sectional surveys. In: Gauthier A.H., Chu, C., and Tuljapurkar, S. (eds.). Allocating public and private resources across generations. Dordrecht: Springer: 117-137. doi:10.1007/978-1-4020-4481-6_5.

United Nations Department of Economic and Social Affairs/Population Division (2005). Living arrangements of older persons around the world. New York: United Nations.

Van Gaalen, R.I. and Dykstra, P.A. (2006). Solidarity and conflict between adult children and parents: A latent class analysis. Journal of Marriage and Family 68(4): 947-960. doi:10.1111/j.1741-3737.2006.00306.x.

Van Tilburg, T.G. and de Leeuw, E.D. (1991). Stability of scale quality under different data collection procedures: A mode of comparison on the 'de Jong Gierveld Loneliness Scale'. International Journal of Public Opinion Research 3(1): 69-85. doi:10.1093/ijpor/3.1.69.

Viazzo, P.P. (2010). Family, kinship and welfare provision in Europe, past and present: Commonalities and divergences. Continuity and Change 25(1): 137-159. doi:10.1017/S0268416010000020.

Victor, C., Scambler, S., Bond, J., and Bowling, A. (2000). Being alone in later life: Loneliness, social isolation and living alone. Reviews in Clinical Gerontology 10(4): 407-417. doi:10.1017/S0959259800104101.

Vikat, A., Spéder, Z., Beets, G., Billari, F.C., Bühler, C., Désesquelles, A., Fokkema. T., Hoem, J.M., MacDonald, A., Neyer, G., Pailhé, A., Pinnelli, A., and Solaz, A. (2007). Generations and Gender Survey (GGS): Towards a better understanding of relationships and processes in the life course. Demographic Research 17(14): 389-440. doi:10.4054/DemRes.2007.17.14. 
Vuorisalmi, M., Pietilä, I., Pohjolainen, P., and Jylhä, M. (2008). Comparison of selfrated health in older people of St. Petersburg, Russia, and Tampere, Finland: How sensitive is SRH to cross-cultural factors? European Journal of Ageing 5(4): 327-334. doi:10.1007/s10433-008-0093-5.

Waite, L.J. and Gallagher, M. (2000). The case for marriage: Why married people are happier, healthier and better off financially. New York: Doubleday.

Walster, E.G., Walster, W., and Berscheid, E. (1978). Equity: Theory and research. Boston: Allyn and Unwin.

Weiss, R.S. (1974). The provisions of social relationships. In: Rubin, Z. (ed.). Doing unto others. Englewood Cliffs, NJ: Prentice-Hall: 17-26.

Wenger, G.C. (1984). The supportive network: Coping with old age. London: Allen and Unwin.

World Health Organization (2002). Active ageing; A policy framework. Geneva: World Health Organization.

Zettel, L.A. and Rook K.S. (2004). Substitution and compensation in the social networksof older widowed women. Psychology and Aging 19(3): 433-443. doi:10.1037/0882-7974.19.3.433. 


\section{Appendix}

Items of the 6-item De Jong Gierveld Loneliness Scale

INSTRUCTION: I am going to read out six statements about your current experiences. Please indicate for each of them to what extent they have applied to you recently:

$1=$ yes, $2=$ more or less, $3=$ no.

\begin{tabular}{lccc}
\hline & yes & more or less & no \\
\hline a. There are plenty of people that I can lean on in case of trouble & 1 & 2 & 3 \\
b. I experience a general sense of emptiness & 1 & 2 & 3 \\
c. I miss having people around & 1 & 2 & 3 \\
d. There are many people that I can count on completely & 1 & 2 & 3 \\
e. Often, I feel rejected & 1 & 2 & 3 \\
f. There are enough people that I feel close to & 1 & 2 & 3 \\
\hline
\end{tabular}

In developing the scale, item response models Rasch and Mokken (MSP) were applied to evaluate the homogeneity of the scale. Scale scores are based on dichotomous item scores; the answer "more or less" always indicates loneliness. Processing the scale data entails counting the neutral and positive answers ("more or less", "yes") on items b, c, e. This is the emotional loneliness score, ranging from 0 (not emotionally lonely) to 3 (intensely emotionally lonely). The emotional loneliness score is valid only if none of the emotional loneliness items have missing values. Count the neutral and negative ("no" and "more or less") answers on items a, d, f. This is the social loneliness score, ranging from 0 to 3 (intensely socially lonely). The social loneliness score is valid only if none of the social loneliness items have missing values. Compute the total loneliness score by taking the sum of the emotional loneliness score and the social loneliness score. The score 0 refers to complete social embeddedness and the absence of loneliness. The score 6 refers to extreme loneliness. The total loneliness score is valid only if no more than one of the loneliness items has a missing value. Further details, the manual and updates are available under 'loneliness scale' at http://home.fsw.vu.nl/tg.van.tilburg/manual loneliness scale 1999.html 
De Jong Gierveld, Dykstra \& Schenk: Living arrangements, intergenerational support types and loneliness 